\title{
Biological studies concerning the antioxidant and antimicrobial activities of Pelargonium species cultivated in Egypt (Family-Geraniaceae)
}

\author{
Abdel Nasser Badawy Singab1, Hala Mohamed El-Hefnawy² and *Dalia Galal El-Kolobby ${ }^{3}$ \\ ${ }^{1}$ Faculty of Pharmacy, Pharmacognosy Department, Ain Shams University, Cairo, Egypt \\ ${ }^{2}$ Pharmacognosy Department, Faculty of Pharmacy, Cairo University, Giza, Egypt \\ 3Pharmacognosy Department, Faculty of Pharmacy, October 6 University, Giza, Egypt
}

\begin{abstract}
Plant-derived pharmaceuticals have become prominent in the market place, making it a favored healthcare choice. In this study, air dried samples of aerial parts of Pelargonium X fragrans Willd. and Pelargonium peltatum L'Hérit. were separately extracted using successive extraction with a soxhlet apparatus. Each extract was tested for its antimicrobial activity using two Gram-negative bacterial strains (Pseudomonas aeruginosa and Escherichia coli), two Gram-positive bacterial strains (Bacillus subtillus and Staphyllococcus aureus), and clinical fungal isolates (Aspergillus niger and Candida albicans). Also, their antioxidant activity was tested using a DPPH free radical assay. The ethyl acetate, n-Butanol and the total extracts showed moderate activity against the tested microorganisms with significant high activity against $E$. coli. The free radical scavenging property was found to be in a concentration dependent manner in all the tested fractions. The most effective antioxidant fractions in both spp. was the n-Butanol fraction (85\% and $85.2 \%)$ at the concentration of $0.375 \mu \mathrm{g} / \mathrm{ml}$ followed by the total ethanolic extracts $(78.1 \%$ and $84.62 \%)$, respectively, with the same concentration compared to the standard reference ascorbic acid which showed a significant radicals scavenging potential $(79.1 \%)$ in the concentration of $1 \mu \mathrm{g} / \mathrm{ml}$.
\end{abstract}

Key Words: antimicrobial, antioxidant, DPPH, P. x fragrans, P. peltatum, Geraniaceae.

\section{INTRODUCTION}

The genus Pelargonium (Family: Geraniaceae) comprises over 280 species of perennial small shrubs. Pelargonium species are native to South Africa and commercially grown in Egypt (Mabbereley, 1997). Traditionally, Pelargonium was used to staunch bleeding, heal wounds, ulcers, uterine hemorrhage and skin disorders, as well as to treat diarrhea and dysentery due to its tannins content (Bown, 1995; Kokkalou and Souleles, 1988). Plants of genus Pelargonium were also successfully employed in modern phytotherapy for their antioxidant (Latte and Kolodziej, 2004), antimicrobial (Lis-Balchin and Deans, 1996), and immunomodulatory effects (Kayser et al., 2001). The reported pharmacological studies on the genus and Clinical trials investigating its use as phytopharmaceutical preparations, indicated that Pelargonium species proved to be effective in treatment of many diseases depending on their antimicrobial activities as acute bronchitis (Theisen and Muller, 2012), peptic ulcer due to Helicobacter pylori (Wittschier et al., 2007). P. x fragrans Known as NutmegScented geranium is a perennial small shrub with Spicy, pine-like fragrance, It has three lobed heart shaped grayish green leaves having trailing clusters of very small whitish flowers with pink veins (Bailey, 1949). Whereas $P$. peltatum (ivy-leaf geranium) is Perennial plant, climbing herbaceous slender-stemmed Leaves peltate, entire, bluntly lobed Flowers umbel-like inflorescences mauve, pink- mauve or almost white Although certain species of the genus pelargonium had attracted the attention of several authors from the Phytochemical and biological point of view, reviewing the current literature reports on
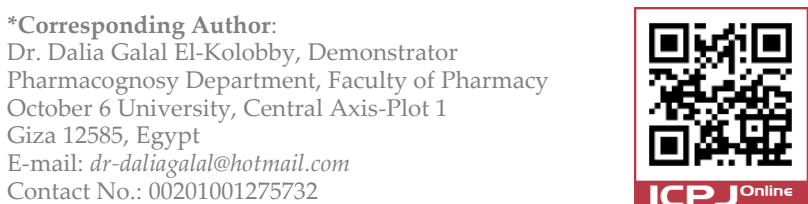

the plant were scanty, so it deemed interesting to investigate the biological activities of the plant, aiming to verify the possible medicinal use. The present article reports the results of biological studies of the total extracts and their fractions thereof (petroleum ether, chloroform, ethyl acetate and $\mathrm{n}$-Butanol fraction) of $P . \mathrm{x}$ fragrans and $P$. peltatum cultivated in Egypt.

\section{MATERIALS AND METHODS}

\section{Plant material}

The aerial parts of $P . \times$ fragrans Willd was collected from The Experimental Station of Medicinal and Aromatic Plants, Faculty of Pharmacy, Cairo University, Giza, Egypt in January 2010. P. peltatum L'Hérit was collected from EL-Sharkiya governorate, Egypt in March 2011. The identity of the plants was kindly confirmed at Flora and Phytotaxonomy Department, Horticultural Researches Institute, Agricultural Research Center, Dokki-Cairo, Egypt. Voucher specimens are kept at Department of Pharmacognosy, Faculty of Pharmacy, October 6 University (\# PF 7010 and \# PP 8011).

\section{Preparation of the Extracts}

Air-dried powdered leaves of $P . x$ fragrans $(200 \mathrm{gm})$ and (100 gm) of P. peltatum were successively extracted using a soxhlet apparatus for continuous extraction using petroleum ether, chloroform, ethyl acetate and n-Butanol, till exhaustion. For each solvent, the extraction was continued until no residue was obtained on evaporation of a small aliquot of the colorless extract to dryness in a watch glass. Before using the next solvent, the powder was taken out of the soxhlet, carefully spread on a sheet of paper and traces of solvent-free powder was packed in the same soxhlet and extracted with the following solvent in the order mentioned before. For each extract, the solvent was removed under reduced pressure at a temperature not exceeding $40^{\circ} \mathrm{C}$. The extracts were dried 
Table 1: Yield of extracts of successive extraction.

\begin{tabular}{ccc}
\hline \multirow{2}{*}{ Successive extracts } & \multicolumn{2}{c}{ Yield percentage } \\
\cline { 2 - 3 } & $\boldsymbol{P . x}$ fragrans & $\boldsymbol{P . p e l t a t u m ~}$ \\
\hline Petroleum ether & 3.22 & 3.8 \\
Chloroform & 2.4 & 0.3 \\
Ethyl acetate & 4.2 & 5.3 \\
n-Butanol & 8.5 & 11.7 \\
\hline
\end{tabular}

to constant weight in vacuum desiccators over calcium chloride and kept for further biological studies (table 1).

\section{Chemicals}

Organic solvents: petroleum ether, chloroform, ethyl acetate, n-Butanol and Dimethyl formamaide; purchased from (Adwic, Nasr Pharma, Egypt), DPPH (2, 2-diphenyl1-picrylhydrazyl) free radical, purchased from Sigma Co., USA., Standardized extract of Vitamin.C. , purchased from Memphis Co., Egypt.

\section{Antimicrobial Activity}

Plant extracts were tested against two standard Grampositive bacteria: Staphylococcus aureus ATCC 25923 and Bacillus subtillus NCIB-3610; two standard Gram negative bacteria: Escherichia coli ATCC 25992 and Pseudomonas aeruginosa NCIB9016; and the fungal strains were (Aspergillus niger Ferm- BAM C- 21 and Candida albicans ATCC 48274 . The culture media used for bacteria was nutrient agar medium, malt extract agar medium used for cultivation of Candida albicans and Czapeks Dox agar medium was used for Aspergillus niger.

Antimicrobial activity test: The strains were first checked for purity on the basis of standard microbiological tests and then used for their sensitivity on the test samples. The bacteria and fungi were maintained on nutrient agar medium and Czapeks Dox agar medium, respectively. The agar media were inoculated with different test microorganisms. The potential antimicrobial activities of the different plants extracts were studied through determination of the zones of inhibition by agar well method (Cooper, 1972). 100 $\mu$ l of each extract diluted with $100 \mu \mathrm{l}$ of DMF and only 50 microliter of solubilized extract was placed in the well. After 24 hours of incubation at $30^{\circ} \mathrm{C}$ for bacteria and 48 hours of incubation at $28^{\circ} \mathrm{C}$ for fungi. Inhibition zones were measured to the nearest mm using vernier calipers.

Standards with the concentration of $1 \mathrm{mg} / \mathrm{ml}$ were used as positive controls miphincol (Misr Co, Egypt) for Gram positive, Keflix (Nile Co, Egypt) for Gram negative bacteria, flucoral (Sedico Co, Egypt) for fungi.

\section{Antioxidant activity}

DPPH radical scavenging activity: The dried extracts were dissolved in ethanol $90 \%$ to a final concentration of $100 \mu \mathrm{g}$ ml-1 (sample stock solution), then the different concentration of each sample $(0.05,0.1,0.15,0.2$ and $0.25 \mu \mathrm{g} / \mathrm{ml})$ were prepared. Several trials had to run to determine the solution concentration that provides an appropriate range of date points. The standard extract of ascorbic acid was prepared in $90 \%$ ethanol to a final concentration $1 \mathrm{mg} / \mathrm{ml}$ and then diluted to serial dilutions of $(0.2,0.4,0.6,0.8,1$ $\mu \mathrm{g} / \mathrm{ml}$ ) to be used as positive controls.

The reaction mixture for each of the fractions consisted of $1 \mathrm{ml}$ of $0.125 \mathrm{Mm}$ DPPH/ethanol solution, $0.5 \mathrm{ml}$ of $0.05 \mathrm{M}$ Tris-HCL buffer (pH7.4) and $1.5 \mathrm{ml}$ of the tested fraction. Decrease in DPPH free radical was measured by reading the absorbance at $517 \mathrm{~nm}$ at room temperature exactly 30 seconds after adding each dilution to the reaction mixture for the tested dilution, that dilution was added to absolute ethanol and buffer to be used as blank

Table 2: Antimicrobial activity studies showing mean diameter of inhibition zones of various fractions of test plants.

\begin{tabular}{|c|c|c|c|c|c|c|c|}
\hline \multirow{3}{*}{ Plant } & \multirow{3}{*}{$\begin{array}{l}\text { Microorganism } \\
\text { Tested fraction }\end{array}$} & \multicolumn{6}{|c|}{ Mean diameter of inhibition zone (mm) } \\
\hline & & \multicolumn{2}{|c|}{ G +ve bacteria } & \multicolumn{2}{|c|}{ G -ve bacteria } & \multicolumn{2}{|c|}{ Fungi } \\
\hline & & B. subtillus & E. coli & S. aureus & P. aeruginosa & C. albicans & A. niger \\
\hline \multirow{4}{*}{ P.peltatum } & Petroleum ether & 11.5 & 12 & 15 & 14 & 11 & 21 \\
\hline & Chloroform & 11 & 15 & 16 & 11 & 15 & - \\
\hline & Ethyl acetate & 14 & 16 & 19 & 18 & 14 & - \\
\hline & n-Butanol & 14 & 20 & 20 & 20.5 & 16 & - \\
\hline \multirow{5}{*}{ P. $x$ fragrans } & Petroleum ether & 18.5 & 16 & 17 & 19 & 13 & - \\
\hline & Chloroform & 13.5 & 14 & 14.5 & 14 & 15 & - \\
\hline & Ethyl acetate & 16 & 17 & 19 & 16.5 & 15 & - \\
\hline & n-Butanol & 15.5 & 20 & 18 & 18 & 14 & - \\
\hline & Standards & $31.5(\mathrm{a})$ & 30(a) & 32(b) & $37.5(b)$ & $25(\mathrm{c})$ & 23(c) \\
\hline
\end{tabular}

a: standard for G +ve bacteria (Miphinicol); b: standard for G -ve bacteria (Keflix); c: standard for fungi (Flucoral)

Table 3: Free radical scavenging activity of different extracts of $P . x$ fragrans and P. peltatum using DPPH photometric method.

\begin{tabular}{|c|c|c|c|c|c|c|}
\hline \multirow{2}{*}{ Plant } & \multirow{2}{*}{ Fraction } & \multicolumn{5}{|c|}{ \% Scavenging of DPPH radical } \\
\hline & & $0.075 \mu \mathrm{g} / \mathrm{ml}$ & $0.15 \mu \mathrm{g} / \mathrm{ml}$ & $0.25 \mu \mathrm{g} / \mathrm{ml}$ & $0.3 \mu \mathrm{g} / \mathrm{ml}$ & $0.375 \mu \mathrm{g} / \mathrm{ml}$ \\
\hline \multirow{5}{*}{ P. $x$ fragrans } & Petroleum ether & N.D & N.D & N.D & N.D & N.D \\
\hline & Chloroform & $2.63 \pm 0.002$ & $10.95 \pm 0.003$ & $20.88 \pm 0.001$ & $35 \pm 0.001$ & $40 \pm 0.003$ \\
\hline & Ethyl acetate & $28 \pm 0.004$ & $57.77 \pm 0.003$ & $74.88 \pm 0.003$ & $76.97 \pm 0.001$ & $79.25 \pm 0.003$ \\
\hline & n-Butanol & $37.47 \pm 0.002$ & $69.15 \pm 0.001$ & $80.23 \pm 0.001$ & $82.91 \pm 0.001$ & $85 \pm 0.002$ \\
\hline & Total extract & $34.2 \pm 0.004$ & $59.3 \pm 0.004$ & $71.2 \pm 0.002$ & $75 \pm 0.002$ & $78.1 \pm 0.002$ \\
\hline \multirow{7}{*}{ P. peltatum } & Petroleum ether & N.D & N.D & N.D & N.D & N.D \\
\hline & Chloroform & $58.65 \pm 0.004$ & $70.1 \pm 0.003$ & $71.71 \pm 0.002$ & $74 \pm 0.004$ & $77 \pm 0.003$ \\
\hline & Ethyl acetate & $21.67 \pm 0.003$ & $53.93 \pm 0.003$ & $60.91 \pm 0.004$ & $75.91 \pm 0.001$ & $79.72 \pm 0.001$ \\
\hline & n-Butanol & $69.24 \pm 0.001$ & $79.58 \pm 0.001$ & $84.37 \pm 0.002$ & $84.43 \pm 0.002$ & $85.2 \pm 0.001$ \\
\hline & Total extract & $58.17 \pm 0.002$ & $69.62 \pm 0.003$ & $79.57 \pm 0.003$ & $83.5 \pm 0.003$ & $84.62 \pm 0.002$ \\
\hline & Vit-C & $0.2 \mu \mathrm{g} / \mathrm{ml}$ & $0.4 \mu \mathrm{g} / \mathrm{ml}$ & $0.6 \mu \mathrm{g} / \mathrm{ml}$ & $0.8 \mu \mathrm{g} / \mathrm{ml}$ & $1 \mu \mathrm{g} / \mathrm{ml}$ \\
\hline & & $15.54 \% \pm 0.001$ & $31.51 \% \pm 0.001$ & $48.18 \% \pm 0.003$ & $64.15 \% \pm 0.001$ & $79.1 \% \pm 0.001$ \\
\hline
\end{tabular}

$\mathrm{N} . \mathrm{D}=$ not detected; $($ Mean \pm SEM) of triplicates 
while DPPH solution was added to absolute ethanol and buffer to be used as negative control.

The $\%$ of antioxidant activity (\%AA) was deduced from the following equation (Munir, 2003):

$\% A A=100-\left\{\frac{(\text { Abs sample }- \text { Abs blank })}{\text { Abs control }} \times 100\right\}$

\section{RESULTS AND DISCUSSION}

Total extracts of air-dried samples of P. peltatum L'Hérit, $P$. x fragrans Willd and their fractions were subjected to biological investigation. Table 2 summarizes the antimicrobial activity of the investigated extracts; the petroleum ether fraction of $P$. peltatum showed a powerful antifungal activity against $A$. niger, it has almost the same activity of the standard flucoral. Ethyl acetate and n-Butanol fractions of both species have a significant activity against all the tested bacteria especially against E. coli, S. aureus. Chloroform fractions of both $P$. peltatum and $P . x$ fragrans had a moderate activity for all tested microorganism. The significant antibacterial activity of the ethyl acetate and nButanol fractions of both species may be attributed to their high phenolic content (Fauconneau, 1997).

Where the antioxidant activity revealed at table 3 that free radical scavenging property was found to be in a concentration dependent manner in all the tested fractions. The most effective antioxidant fractions of $P . \mathrm{x}$ fragrans and $P$. peltatum was the n-Butanol fraction $(85 \%$ and $85.2 \%$ ) at the concentration of $0.375 \mu \mathrm{g} / \mathrm{ml}$ followed by the total ethanolic extracts $(78.1 \%$ and $84.62 \%)$ respectively, with the same concentration compared to the standard reference ascorbic acid which showed a significant radicals scavenging potential $(79.1 \%)$ in the concentration of $1 \mu \mathrm{g} / \mathrm{ml}$. The high activity of the n-Butanol fraction is probably due to the presence of phenolic substances, where DPPH free radical abstracts the phenolic hydrogen of the electron donating molecule (Fauconneau, 1997).

\section{CONCLUSION}

This study presents the free radical scavenging and antimicrobial activities of $P$. peltatum and $P . \times$ fragrans, the preliminary microbiological investigation encourages establishing further studies on broader range of microbial strains and, the above study was effective for selection of the most effective antioxidant fraction (n-butanol), furthermore detailed studies on the chemical composition of that fraction is essential to isolate antioxidant agents. It could be concluded that the plants is of phytopharmaceutical importance and studies with these plants may yield nature friendly strong antioxidant, anti-fungal and antibacterial agents of medicinal importance.

\section{REFERENCES}

Bailey, L.H. (1949). Manual of cultivated plants most commonly grown in the continental United States and Canada. Macmillan, New York, U.S.A". P.597.

Bown,D. (1995). "Encyclopedia of herbs and their uses", The Herb Society of America, (1st Ed., P.172) Dorling Kindersley Ltd.

Cooper, K.E. (1972). “Analytical Microbiology F.W. Kavanageh, (E.D). Vol. I \&Џ, Academic press, New York and London.

Fauconneau, B., Waffo,T.P., Huguet, F., Barrier, L., Decendit, A., Merillon, J.M.(1997). Comparative study of radical scavenger and antioxidant properties of phenolic compounds from Vitis vinifera cell cultures using in vitro tests. Life Sci. 61 (21). [DOI]

Kayser, O., Kolodziej, H., Kiderlen, A.F. (2001); "Immunomodulatory Principles of Pelargonium sidoides.", Phytother. Res., 15(2), 122-126. [DOI] PMid:11268110

Kokkalou, E. and Souleles, C. (1988). "Flavonoid Constituents of Pelargonium $x$ asperum Enrh. ex Willd. Geraniaceae." Plant Med. Phytother., 22(4), 247-253.

Latte, K.P. and Kolodziej, H. (2004) "Antioxidant properties of phenolic compounds from Pelargonium reniforme.", J. Agric. Food Chem., 52(15), 4899-4902. [DOI] PMid:15264932

Lis-Balchin, M. and Deans, S.G. (1996). “Antimicrobial effects of hydrophilic extracts of Pelargonium species (Geraniaceae). Letters in Applied Microbiology. 23 (4): 205-207. [DOI] PMid:8987691

Mabbereley, D.J. (1997). “The plant Book”, (2nd Ed., P.536). Publisher: Cambridge University Press.

Munir, O., Ihami, G., Rafn, O. and Kufrevio, L. (2003) "Determination of In vitro antioxidant activity of Fennel (Foeniculum vulgare) Seed Extracts." Lebensmittel-Wissenschaft und Technologi, 36(2), 263-271. [DOI]

Theisen, L.L. and Muller, C.P. (2012). “EPs® 7630 (Umckaloabo®), an extract from Pelargonium sidoides roots, exerts anti-influenza virus activity in vitro and in vivo." Antiviral Research. 94(2): 147-56. [DOI] PMid:22475498

Wittschier, N., Faller, G. and Hensel, A. (2007). An extract of Pelargonium sidoides $(\mathrm{EPs} \circledast 7630)$ inhibits in situ adhesion of Helicobacter pylori to human stomach. Phytomedicine. 14(4):285-8. [DOI] PMid:17350240 